\author{
Krystyna KujaWińsKa Courtney \\ University of Łódź
}

\title{
THE MARGINALIZATION OF LUCRECE'S STORY IN THE EARLY MODERN POLISH CULTURE
}

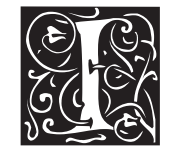

$n$ Poland, the motif of Lucrece first appears in works written in Latin, an example of which is the poem Deliberatio Lucretiae Romanae, written in hexameter, probably as a school exercise by Marcin Kromer (1512-1589). ${ }^{1}$ He later became well known all over Europe through his service as the Bishop of Ermland [Pol. Warmia], as well as for his skill as a cartographer, diplomat, and historian. The Lucrece's theme was also taken up by Jan Dantyszek [Lat. Johannes Dantiscus, also known as Jan Flachsbinder] (1485-1548), an internationally renowned poet, politician, and diplomat; unfortunately, his Latin work "De Lucretia Barbara" has been lost.

A short time later, works written in Polish also appeared. The first of these was penned by Jan Dymitr Solikowski (1539-1603)2 , who dedicated his

1 The text of this essay was originally written in Polish, and I would like to express here my gratitude to Ms. Anna Jędrzejewska for translating it into English.

2 Although towards the end of his career Solikowski became Archbishop of Lvov, he had also successfully served as a diplomat as well as secretary to King Sigismund Augustus. In addition, he authored numerous political and historical works, as well as poetry. Polish access to the sea constituted one of his most pressing concerns. In one of his state papers Solikowski stated: "Every sovereign and every nation knows the importance of the access to the sea. The countries which possess it, and do not use it, or allow the others to take it from them, deprive themselves from many benefits. They bring upon themselves innumerable woes, turning from free countries into dependent provinces, and losing their riches". (qtd. "Historia Marynarki Wojennej RP”) 
eight-page poem Lucrecya rzymska i chrzescijanska (Lucretia Romana and Christiana, 1570) to "Her Ladyship Dorota Krzysztoporska, Chatelaine of Wielun". Julian Krzyżanowski sees this dedication as a result of Solikowski’s friendship with Mikołaj, Krzysztoporski's son, dating back to their university years in Wittenberg. It was probably also Solikowski's expression of gratitude to Jan, Krzysztoporska’s husband, for his help in securing Solikowski's first diplomatic post (Krzyżanowski,1962: 215-216).

The main text of the poem is preceded by "A Short Foreword" by Andrzej Trzycieski (ca. 1530-1584). ${ }^{3}$ At the time, Trzycieski was a well-known writer, poet, translator, and supporter of the Reformation. He had also studied alongside Solikowski at Wittenberg. ${ }^{4}$ Preparing Dorota Krzysztoporska to read the poem, Trzycieski introduces the theme of virtue, which

had in olden days been held in such honour by heathens, that they would often gladly their lives for her have given and for that immortal glory have earned' $(2-4) .^{5}$

Because martyrdom is only one of the poem's themes, Trzycieski notes that men are not the only ones who can become martyrs: "we do have of the fair sex examples aplenty" (5-6). To illustrate this, he uses both Lucrece and St Pelagia, who "while but a maiden from a height did leap / and thus a greater feat [than Lucrece] did accomplish / being pure and intact as she did so do" (13-16). Praising,"until the ages of this world do pass" (18-19), the glory of these two women, who had both sacrificed their lives in defence of their virtue, Trzycieski does not make a qualitative distinction between the life of the pagan Lucrece and the Christian Pelagia. ${ }^{6}$

3 All citations from the poems come from Krzyżanowski's edition (1936).

${ }^{4}$ As a philologist, Trzycieski, who was fluent in Hebrew and Greek, was included in the team of translators that involved in preparing the Calvinist Brest Bible under the patronage of Duke Mikolaj Radziwill "the Black" in Pinczów. Trzycieski’s work, in both Polish and Latin, included numerous lyrical poems, pamphlets in verse, elegies, epigrams, as well as religious hymns, which could be found in numerous Calvinist hymnals.

5 All translations are given in prose though in the case of poems they preserve their verse structure.

${ }^{6}$ St Pelagia, who lived in the $3^{\text {rd }}$ century AD, came from a Christian family in Antioch. She was 15 when persecutions of Christians under Diocletian, or indeed his predecessor, Numerian, began. When Roman soldiers came to arrest her, she, having heard about prisoners being raped and tortured, asked to be permitted to dress for the journey. Having 
Religious issues do not, however, play a significant role in this Foreword, as its main purpose is to praise the virtue of "Her Ladyship" [Dorota Krzysztoporska], which may serve as an example of "true love" (26-27) to other women "so they may true Lucreces be called / and with greater glory be honoured, Eternal Lord" (28-29). This panegyric by Trzycieski is followed by the main body of Solikowski's poem, whose two sections, "The Roman Lucrece" and "The Christian Lucrece", depict the martyrdom and suicide of Lucrece and St Pelagia, respectively, and praise their virtue.

"The Roman Lucrece" is a loose adaptation of Ovid's poem Fasti, although on a few occasions Solikowski introduces into the conversations between Lucrece and Collatine his own philosophical and theological views on the difference between the pure, untarnished soul and the sinful body:

Said he [Collatine] that "it is the mind and not the flesh that sinneth so when the mind hath stayed undefiled, thou canst rejoice that while the flesh hath suffered a wrong, but the thought hath not been raped thou canst be sure thou hast stayed entire

The deed forced on you we thee forgive but the Tarquins our anger shall know".

To which she [Lucrece]: "Though you forgive me you will still know a different mind of mine I want a memory and an example of my virtue behind me to leave for Roman ladies never do disgrace condone" (139-148).

The section of the poem entitled "The Christian Lucrece", which tells the tragic story of a young woman, inspired by the life and death of St Pelagia, is of a completely different character. The only element of the original hagiographic text that is retained in Solikowski's poem is the message that the preservation of virginity is worth sacrificing one's life through suicide. The heroine of the poem is not a twelve-year-old girl, as it is in St. Pelagia's case, but a young woman who the queen's son is plotting to rape. Lured into a trap by the queen, the woman realises that her persecutor will soon appear, and seeking help in God, she places herself in His hands and leaps out of the window:

thus distracted the attention of her captors, she ascended the roof of the house and leapt to her death. The Church considered this act of suicide to have been committed in defence of the faith and her virginity. On this basis, Pelagia was deemed a martyr and a saint. 
My Lord, when this man is so intent

please let this your servant keep her mind intact.

I must the only rescue left to me pursue,

when this rape I can no more escape (63-66).

An innovative feature of the poem is the presence of another woman-the queen-as an accomplice in the young woman's downfall. The rape is planned with her full knowledge and approval. In this way, Solikowski's poem raises not only the issue of the lack of solidarity between women, but also the problem of the corruption of authority, which affects both men and women.

If we take into consideration the fact that the average lifespan in the sixteenth-century Poland was, at just over 30 years ("Folwark szlachecki i chłopi"), significantly lower than at present, it is not surprising that the thirty-one-yearold poet adopts the standpoint of an experienced man, not only offering advice to young people, but also sharply criticising them [sic!]. He addresses them with full confidence in his own righteousness and in the integrity of his moral judgements, offering a word of warning: "when shamelessly your passions you follow, much cause for wrongdoing to others you give" (81-82). In its final section, the poem acquires a didactic and moralising tone as the poet warns parents of the consequences of failing to morally educate their children: "Take care, so that you do not later weep, / if you the young to do ill permit" (85-86).

Solikowski's criticism also extends to poets ("Why with your poems do you the world spoil?" (88) and artists ("Why such shameless works do you make, Jove's all vanities, Mars and Venus' doings?” (101-102)). His accusations regarding the poets' role in promiscuity and the demoralisation of women probably reflect his general assessment of everyday life in Poland, as well as the quality of its art. Condemning the looseness of Roman sexual mores, which in the cases of both Lucrece and St Pelagia targeted the virtue of innocent women, the poet laments the state of culture in Poland: "All now in Poland the Italian way has gone; / there is wickedness everywhere, and very little shame" $(110-111)^{7}$

A second piece on the theme of Lucrece published in Polish at the time was an anonymous poem entitled Historia o Lucrecyey Rzymskiej Pobozney y szlachetney Matrony Uczciwym y Cnotliwym Mezatkom Przyklad Wieczny [A His-

7 In his analysis of the poem, Julian Krzyżanowski describes Solikowski's poem as an example of humanist tendencies that, under the influence of the Counter-Reformation, were being revived in Poland at the time. 
tory of Lucrece of Rome, God-Fearing and Noble Matron, to Honest and Virtuous Wives an Eternal Example]. ${ }^{8}$ This work, full of passages of high lyrical intensity, is undoubtedly of significant aesthetic merit. Its message is reminiscent of that of mediaeval exempla, aimed at illustrating moralistic discourses present in mediaeval didactic literature and homiletics. An important part of the poem is formed by Lucrece's despairing monologues, typical of the popular literary sub-genre of the Renaissance period, the "lament".

Polish Renaissance scholars have not been able to establish whether Historia o Lukrecyey Rzymskiej Pobozney is an original work or a translation. Its author doubts (quite unnecessarily) his/her poetic powers, concluding the opening section of the work, "Ad Zoilum", with the request "If some wise person a mistake doth find, / please forgive the less learned author". A reading of the poem demonstrates that it was written with a high level of artistic skill, particularly evident in the sections of the text spoken by Lucrece:

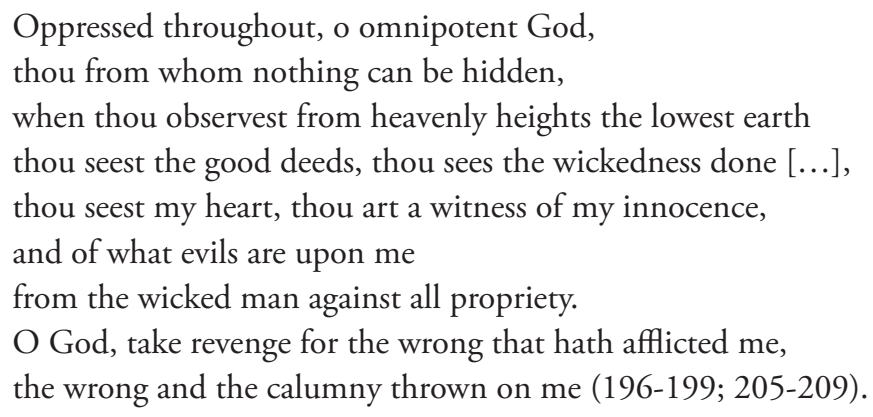

Also worth noting are the sections of the poem in which Lucrece complains that the cause of her tragedy is her sex:

Woe is me! Why have I into the world been born?

If only I had in my mother's womb perished, and not in such trouble lived, nor into such an affliction survived, nor to my virtue the slightest damage suffered.

${ }^{8}$ According to Krzyżanowski, some scholars ascribe the poem to the little-known Marcin Luterna. Krzyzanowski does not share this view.

9 This sub-genre was originated by Ovid in his Heroides - a collection of fifteen love letters in verse in which fifteen heroines of ancient myths lamented their suffering at the hands of their lovers (e. g. Medea, Penelope, Phaedra, Dido, Ariadne, Deianeira, Sappho). See for example: Holst-Warhaft (1992). 
Unhappy, I say, thrice unhappy am I, of all of the fair sex, for what I valued more than my soul against my will I have lost, and for which I now have to weep (242-250).

An innovative element is the inclusion at the end of the poem an epitaph which Collatine, in his despair, has engraved on her tomb:

Here lies Lucrece, who, by her great love of virtue driven, at once to take revenge for her grief, both her revenge and her life with a sharp iron she did end.

Such a bargain with this world she did make, for over her life her virtue she did treasure. [...]

For years unending may the loss of her innocent life remain famous (346-351; 269-270).

The poem does not raise political questions because the issue of revenge on the Tarquins remains private. Collatine promises revenge, which is meant to "redeem the innocent grief [of his wife],/ redeem her innocent death" (369-370).

Other authors who dealt with the theme of the tragic fate of Lucrece include Andrzej Krzycki (1482-1537), the Primate of Poland. He was both politician and poet, as well as author of the didactic piece Historia Rzymskiej Lukrecji, Cnotliwej i poboznej matrony uzyta jako wieczny przyklad uczciwej i bezgrzesznej kobiety zameznej [A History of Lucrece of Rome, a virtuous and God-fearing matron, used as an eternal example of an honest and sinless married woman]. There was also an anonymous narrative poem "Historia Rzymskiej Lukrecji” [“A History of Lucrece of Rome"] in circulation. Furthermore, Zbigniew Morsztyn (1625-1688), a seventeenth-century Polish poet, mentioned Lucrece's name in his 1684 poem "A Carol".

A notable aspect of the reception of the myth of Lucrece in sixteenth-century Poland is its absence from public debate. There are no documents indicating the use of that story in any supporting commentary on current public events. ${ }^{10}$ In other European countries, however, references to the motif of Lucrece was present, for example, in pamphlets, scholarly treatises, creative

10 This was the role played by the myth of Lucrece in England, which is demonstrated by the fact that it is referenced in England's Parnassus, or The Choicest Flowers of our Modern Poets, an anthology of poetry published in 1600 by 'R. A.' [Robert Allott]. 
appropriations and translations. These dealt not only with the theme of suicide, but also addressed debates about the political system, the monarchy, republicanism, and civic responsibility (103-142) (Kujawińska Courtney 2012, 59-74).

The popularity of the myth of Lucrece increased in times of political crises, encouraging opposition against tyranny, particularly when the monarchy attempted to strengthen its authority at the expense of the legislative powers of parliaments or of the aristocracy. "During the Renaissance, like in ancient Rome”, explains Katherine Baseman Maus,

the story of Tarquin and Lucrece displayed vividly the inextricability of domestic and civic order, of public and private realms, of sexual and political violence, as a political fable; it suggested circumstances in which subjects were permitted, even obliged, to challenge the authority of their sovereign.

"When Tarquin rapes Lucrece," Baseman Maus adds, "he does not merely perpetrate an act of brutal violence against her, but he defiles Collatinus's exclusive claim on his wife's body, imagined as the husband's property (Baseman Maus 2005, 663; emphasis in the original).

It is possible that it was the political situation of Poland in the sixteenth century that resulted in a lack of interest in the myth of Lucrece: after the creation of the Commonwealth of the Two Nations in 1569-Poland and Lithuania-Polish political thought was dominated by the ideology of republicanism. This was a consequence of the attempts, over the previous two hundred years or more, of the aristocracy and the gentry to obtain a guarantee of their civic freedoms in legislative and executive spheres. Summarising the political situation in Poland in the second half of the sixteenth century in his famous treatise Polonia defensa contra Ioannum Barclaium (1648), Łukasz Opaliński the Younger explains: "We have a king, but we are neither his inheritance nor his patrimony [...] because he exists for his citizens, and not his citizens for him" (qtd. Pendrich 2009, 103). In other words, the fact that from 1573 on Polish gentry secured the right to freely elect the monarch meant that, although the gentry fully accepted the existence of the monarchy as an institution, the myth of Lucrece did not attain the level of significance it enjoyed in political debates elsewhere in Europe.

With the issues of virtue and suicide reduced to the private sphere, the myth of Lucrece was rather quickly marginalised in Polish culture. It was mainly used for didactic purposes: a review of Polish textbooks used over the centuries 
for the study of Latin indicates that the other fragments from Livy's Ab urbe condita were preferred. ${ }^{11}$

Excerpts of Livy's work became available to the Polish reader only in 1965, ${ }^{12}$ while Ovid's Fasti, which had for centuries been one of the sources for the myth of Lucrece, were not translated into Polish until the twenty-first century (2008). A better fate awaited Shakespeare's narrative The Rape of Lucrece, the first translation of which was published in 1922 by Jan Kasprowicz. When one considers one-sentence entries on Lucrece in dictionaries, encyclopaedias, and lexicons, the lack of reference to her in the work of Polish artists is not surprising. In other words, this female figure, one of the most famous in sixteenth-century Europe, never took her rightful place in the pantheon of Polish culture.

Relegated to the domestic sphere-marital innocence and virtue- - she was never granted her own history. She suffered the same fate as many other heroic women in the history of the Polish nation, whose lives tended to be seen, evaluated, and commemorated primarily through the lens of the activity and achievements of men.

11 Textbooks used in the English and American educational systems usually include the myth of Lucrece in their selections of Latin texts.

12 At present the Polish reader has access to five volumes of translations from Livy's work: The History of Rome ab Urbe Condita, Books I-V, translated by A. Kosciółek, introduced and edited by M. Brożek (Wrocław, 1988); Books VI-X , translated by A. Kosciółek, and with a translation of summaries by. M. Brożek and a commentary of Books XI-XX by J. Wolski and M. Brożek (Wrocław, 1971); Books XI-XX, translated by M. Brożek and with M. Brożek's commentary (Wrocław, 1974); Books VIII-XX, translated and edited by M. Brożek (Wrocław, 1976); Books XV-XV and XX translated by and edited by M. Brożek and J. Wolski (1981); Excerpts from Livy's History, translated and edited by W. Strzelecki (Wrocław, 1965). 